\title{
Public sphere contestation: configuration of political Islam in contemporary Indonesia
}

\author{
Zuly Qodir
}

Faculty of Social and Political Science, Universitas Muhammadiyah Yogyakarta

E-mail:zuly_qodir@yahoo.com

\begin{abstract}
Argument in this paper draws upon Habermasian understanding of the distinction between private and public sphere. Public sphere is understood as open space that various social and cultural forces seek to define and occupy by ways of rational interests and public reason. Such attempts take place on daily basis and taken by groups of different backgrounds and interests. Private sphere, in contrast, is conceived of as having domestic or individual characteristics and, more or less, non-political. It is within this framework that the continuing presence of multiple variants of political Islam in Indonesia has been a manifestation of contestation over public sphere. Diverse variants of Indonesian political Islam reveal the difference between actors and issues in the dynamics of their contention. However, evidence makes clear that variants of both political and popular Islam have been more dominant than other Islamic variants such progressive and neotraditionalist Islam. This study argues that mode of Islamic articulations in Indonesia is now more diverse as the it has developed not only in the articulatory forms of modernist, revivalist and traditionalist but also progressive, neo-traditionalist and popular Islam.
\end{abstract}


Tulisan ini didasarkan pada kerangka ruang publik Jurgen Hubermas yang membedakan ruang privat dan ruang politik (publik). Ruang publik merupakan ruang yang terbuka untuk diperebutkan oleh siapa pun dan kapan pun. Sementara ruang privat merupakan ruang yang bersifat domestic (individual) tidak berdimensi politik secara dominan. Dalam persepktif semacam itu, hadirnya varian-varian Islam Indonesia merupakan bentuk kontestasi atas ruang publik yang terbuka untuk siapapun. Dari varian-varian Islam Indonesia, ada perbedaan aktor dan isu yang dikembangkan dalam kontestasi publik. Hanya saja kontestasi varian Islam politik dan popular mendapatkan ruang lebih dominan ketimbang varian Islam lain seperti progresif atau neo-tradisionalisme. Kajian ini menunjukkan bahwa Islam Indonesia tengah mengalami perkembangan format artikulasi yang sangat beragam. Islam Indonesia tidak hanya berkembang dalam format modernis, revivalis, tradisionalisme, tetapi sekaligus progresif, neo-tradisionalis dan popular Islam.

Keywords: Indonesian Islam; Variant; Public Sphere; Contestation

\section{Introduction}

Indonesia witnesses the growth and dynamics of Islamic parties. In Reformasi era, Islamic parties always involve in electoral process and have contributed no less than five parties. Between 1999 and 2009, there have been at least 7 Islamic parties taking part in general election. But their trend in terms of electorate gains is decreasing. This explains that Islamic parties have been undergoing deterioration credibility before their actual and possible constituencies. This also indicates how the growing number of Islamic parties has not gone together with the clearer vision and objectives of the parties. Islamic parties are no more than a mere idea or set of ideas within significant segments of Muslim community that tends to preserve 'syahwat politik' (political lust) by arguing that political Islam in Indonesia has long origins tracing back to pre-Independence period. 
This worsening condition does not come from nowhere or without hints. There has been long process leading to the current condition. One of the major factors is patron-client practice that orients the actors into the only struggle for power. Politicians among Islamic parties, time and again, show no respect for ethics in doing politics. It reveals the strong traits of Darwinism in politics in which they prioritize their own short-term interest rather than long term national projects. This condition, according to Mochtar Masoed, is understood as political survival, a sort zero zum game of contention among power contenders. If we use the words of Pramoedya Ananta Toer, we are now entering the period of extraordinary political crime in which corruption has become the nature of the politics and the politicians are the main perpetrators.

Politics of the Santri has lost its moral strength and public sympathy as its actual agenda is to use power for their own interest instead of defending greater common goods. Moral, or political fatsoen, has been so low that it is almost impossible now to distinguish between Muslim politicians and non-Muslim politicians. More and more politicians of Islamic parties put into jail because of corruption, pornography, practices of marking up projects' budget that deteriorate public life. All these committed by Muslim politicians.

Against this backdrop, ideological orientations among Islamic parties are worth questioning. Orientation in their ideology by making use of Islam is just an false appearance that seeks to hide their bad intention and behaviors. They are busied themselves with efforts to build up their own image as moralist, 'clean', and populist. PKS, for instance, which was since its inception an ideology-based, has now chosen to be pragmatist as the party officials tend to exploit the language of laws and morality. As the evidence shows, this shift does not affect the party's electorate gains between 1999 and 2009. What we can con- 
clude is that Islamic parties fail to address broader public of citizenships and their attempts at making good profiling of themselves are perceived by the public as tricky and power- preserving. The majority of Muslims in Indonesia does not correlate with the present state of decreasing power of Islamic parties.

It is worth emphasizing here that one among other factors contributing to this weaknesses is the fact that electorate behaviors among Muslim voters are very much influenced by cultural cleavages or cultural origins of Islamic parties that have caused deeper rifts and contention within Indonesian political Islam. Though the parties are criticized by broader public of voters and scholars, electorate behaviors of the voters remain subject to the cultural backgrounds that now labeled as modernist-rationalist, traditionalist-Islam, and progressive-Islam.

A case in Muhammadiyah is one of best example. Following their discontent with the performance of Muhammadiyah politicians in PAN (Partai Amanat National), Muhammadiyah stakeholders/participants of Tanwir's general meeting in Banjarmasin 2005 planned to establish new party, PMB (Partai Matahari Bangsa). Comparable case can be seen in Nadlatul Ulama when a number of Kiai are very disappointed with the performance of Abdurrachman Wahid againts whom they built up Partai Kebangkitan Nahdlatul Umat (PKNU). It is also the case within PPP (Partai Persatuan Pembangunan) when KH Zainuddin, so called Kiai of a million supporters, established Partai Bintang Reformasi (PBR). Lesson we learn from this phenomena is the fact Muslim politicians from various Islamic parties are fighting for holding power in the same arena and targeting both modernist and traditionalist bases of constituencies. Modernist Muslims of Muhammadiyah are targeted by PAN and PMB, while traditionalist Muslims of NU bases targeted by PKB and PKNU. ${ }^{1}$

${ }^{1}$ Zainuddin Maliki, Sosiologi Politik, Yogyakarta: Gajah Mada Press, 2010. 
Looking more closely, most of the voters have little knowledge or information about what is the party and its function in democratic society. Consequently, basis of their political preference is much more emotional attachment to certain patrons or leaders in the parties. Abdurrahman Wahid is one of the PKB prominent figures whose political capital goes beyond other Kiai. In PAN, while perceived as modernist Islamic party, Amien Rais has occupied central position that the party exploits for electorate gains. We can say that the voters are not rational, let alone their broad understanding of the importance of the parties. PKB of Abdurrahman Wahid has so far remained in the big five. It is also the case for PAN, that while there is no formal instruction for all members of Muhammadiyah to choose PAN in 1999, 2004, and 2009, PAN's electorate gains are far larger than the late-coming PMB.

PKB, PKNU, PAN and PMB are among the list of Islamic parties whose electoral power has deteriorated since 1999. The fall of Islamic parties results from their own bad performance, particularly their inability to put into practice political ethics. The politicians no longer able to follow the footsteps of the founding father of Indonesian political Islam such as M. Natsir, Prawoto Mangkusasmito, Kasman Singodimedjo, Mr. Jusuf Wibisono, Agus Salim, Cokroaminoto, Syafruddin Prawiranegara and many others.

There are many other factors contributing to the fall of political Islam in Indonesia. One of them is that Islamic parties agenda is short termed as the politicians have no other vision than struggle for power. General interests of the Islamic community, particularly prosperity, is far from being represented in parliamentary decision making. Instead of Islamic interests, their true ideology is power-seeking. As we always witness, power-sharing and sharing opportunity among politicians become their present characteristics which are not Islamic in nature. 
Of course, we do not deny the fact that Islamic parties are not completely withering, but their performance to attract broader public attention has been lost significantly. This is reflected through their decreasing electorate gains that do not correlate to the Muslims as the majority religion in this country. This might tell us the shift underway from formalization of Islam politics toward more substantialization of public life of the Islamic community. Another reason for this shift is that the public has lost trust to the parties and comes to understand the practices of Islamic parties today as mere continuity of the past about which Islamic parties is not distinct from other non-Islamic parties. The public see no difference between them in practice, and the difference is mere ideological statement and political rhetoric. This, however, is worth studying by scholars on political Islam and also those activists of political Islam with whom the transformation might be possible in future. Attention to political Islam in Indonesia is very much required for one simple reason, namely, Indonesia is a country of the biggest Muslim population in the world, and generally conceived of as moderate in their political inclination and not radical or showing theocratic appeal.

In this paper we will offer critical notes on the development of Islamic movements during the last ten years in Indonesia. This is a preliminary note, if not introductory, in need of further elaboration for attaining larger and comprehensive picture of Islamic movement framework. Focus on the last ten years does not mean that we put aside the Islamic movements in 1990s. During decade of 1990s, the emergence of political Islam is in early stages of its development, while in $2000 \mathrm{~s}$ the movements has found its more established mode of articulations asthe political spaces are increasingly open and contingent. Question about what Islamic parties that will win the future political contestation 
is worth asking since answer to this question will consequently affect future patterns of political Islam in Indonesia. this is challenge to which Islamic scholars and activists must seriously address.

\section{Politicizing Islam}

Politicizing Islam is reflected through parties under the banner of Islam. It comprises PPP, PBB, PK, PKNU, and PBR. This sort of Islamic parties is the legacy of fundamentalist Islam which operates in political arena of the state like Ikhwanul Muslimin and HTI. The last two movements attempt at formalizing Islam into political arena.

As we already know, Islamic parties have recurrently emerged in electoral politics between 1998 and 2009, as once entered political arena in 1955. It is highly possible that their involvement will take place in future general elections. The most interesting is that their emergence is marked by the changes of parties as showing their internally contentious dynamics. Though many of them unable to qualify as results of minimal administrative requirement and minimal electorate gains, Islamic parties stand still and develop. With these two administrative requirements, many of them could not participate in the future election. Consequently, the failed parties must change their profile and name in order to establish the new ones: new parties but old politicians.

The question is why, in the backdrop of Muslims as majority of the population $(88,57 \%)$, the Islamic parties could not win the the hearts and minds of the majority? This is the challenge for Islamic activists in political arena. Assuming that under the banner of Islam they would win the election is completely false. Next question is from which does the commitment of Islamic parties must be drawn? Have the ideology and programs become core issues for the the parties to address? Do their programs really attract the voters or, in contrast, the programs 
do not accommodate the general interests of the Muslim constituencies?

Put this differently, Islamic parties are no longer popular among Indonesian Muslims. The parties is not distinct from nationalist parties. Both strands are fond of capital accumulation for the party machine and organizations rather than for bringing welfare to the people. They do not have strong and permanent constituencies, even to the extent they have no precise assessment on who or what group they are actually representing in political arena. People, as political constituency or voters, emerge in time of election as they cling to the cultural or economic patrons who are the candidates. Effects of patronage and image of political parties are so deep that ideology or programs have little influence. Voters for Islamic parties seem indistinguishable from voters of non-Muslim backgrounds or nationalist articulations. The voters, in fact, chose the parties to articulate their interests which are urgent like employment, and betterment of public services. Their hope is that the parties represent their interests as they are desperately coping with grinding poverty, high cost of housing, education and health services. These demands are not responded by the parties.

It is within this deteriorating performance that we become more confused with the current phenomena in which young Muslim politicians seek to establish new parties under the banner of Islam and pretend to represent the majority of Muslims in Indonesia. The lack of public support does not weaken their pragmatist behaviors. Sociologically speaking, instead of reforming the parties and their understanding, the politicians keep on their tracks. They deny the sociological reality upon which the parties emerge and fall. We can say that the Islamic parties are anti-history as they negate the historical fact of their performance and lack of support from general public. So far, there have had no hints 
that the politicians will reform the parties or think about the need not to establish new Islamic parties.

However, there has been a perception among the politicians in response to the lack of public support. Instead of reforming their behaviors, they argue that such lack reflects the phenomena of un-Islamic or less understanding of Islam among Muslims. The public knowledge on Islam is perceived as commonsense that makes them prone not to chose Islamic parties. Is it true that Muslim community has not attained the level of being complete Islamic? This question, of course, elicits various responses for the simple fact that there are multiple interpretations of the relation between Islam and politics among Muslims in Indonesia. the debate remains as to whether political Islam is integral to Islamic doctrines, or space of ijtihadiyah is contingent that offers greater option for the Muslim to chose Islamic parties or nationalist parties. In other words, the debate revolves around the question of whether the establishment of Islamic party is legitimate or illegitimate. It is at this point that the frontiers between Islam and politics in Indonesia are far from clear even among the Indonesian Islamic scholars.

Just to remind, debate on whether Islam and politics are integral or separable has been the legacy of revolutionary period in 1940s. In time of high debate on state foundation, offering the option between Pancasila and Islam. There was productive tension between religiousIslamic camp and secular-religious camp. Secular-religious camp consists of M. Yamin, Soekarno and Hatta while Ki Bagus Hadikusuma, Wahid Hasyim, KH. Masykur and Kasman Singodimedjo belong to religious-Islamic camp. Secular-religious won the debate without triggering social tensions among their proponents in society. Absence of bloody conflict reflects how both camps are subject to political ethics or 'fatsoen 
politics' that binds religious communities for the sake of the nation rather than their sectarian interests. Primacy of political ethics has been the very normative clue in doing politics in multi-cultural Indonesia. this can be seen in the study undertaken by Ahmad Syafii Maarif concerning the constitutional debates in Indonesia. ${ }^{2}$

\section{Revivalist Islam}

Islam revivalism reflects the neo-fundamentalist orientation among Muslims as indicated through Wahabi movement with strong attachment to Arab Saudi and Middle East in general. With the spirit of PanIslamism modeled on the preaching of Muhammad ibn Abdul Wahab, this movement has developed in Indonesia. Though initially propagated by Jamaluddin al-Afghani and Muhammad Abduh, political tradition of Islamic fundamentalism has been influenced at large by the preaching of Muhammad Ibn Abdul Wahab which now occupies the broader public of Muslim community in Indonesia and Southeast Asia in general.

Islam revivalism is in fact the legacy of international Islamic activists or movements, or trans-nationalist Islam that struggle for the return of Pan-Islamism in modern world. Pan-Islamism is employed to the extent that it empowers Muslim communities around the world to attain political power. It becomes the instrument of power-seeking among Muslim activists across the globe. All draws upon the urgency of purifying Islamic teachings but then has shifted into political movement with strong objective to regaining the influence of Islam at international level. Pan-Islamism is perceived as of having succeeded in uniting Middle East.

In the tradition of political Islam, spirit of Pan-Islamism is widely known as Islam neo-fundamentalism, or Islamic politics with sole agenda

\footnotetext{
2 See Ahmad Syafii Maarif, Islam dan Masalah Kenegaraan, Jakarta: LP3ES, 1987.
} 
of establishing Islamic state and not Islamic society. This movement differs from both Muhammadiyah and NU. Agenda of Muhammadiyah and $\mathrm{NU}$ is to create Islamic Society, while the Islam revivalism is to establish Islamic State. The most active movement of this revivalism is Hizbut Tahrir (including Indonesia Hizbut Tahrir) as it calls the Islamic State with khilāfa Islāmiyya, led by a khalifa within Islamic model of government.

The notion of Pan-Islamism in Indonesia can be clearly elucidated in the activities carried out by political groups such as Hizbut Tahrir in Indonesia, as the latter struggles for khilafa Islamiya. On the other hand, the notion of Islamic Society in Indonesia can be seen in the activities of Muhammadiyah during the last century up to the fortysixth Muktamar (grand meeting) in Yogyakarta in 2010. The goal of the meeting was to build up civilization and society through the guidance of God without proposing the agenda of establishing Islamic foundation of Indonesian state. For Muhammadiyah, Islam is its sole foundation. The movement's consistency and commitment are always put at stake when the small groups within the movement pursue different agenda for making Islam as the foundation of Indonesian state. But until now the movement remains within its historical track of Islamic Society. ${ }^{3}$

For a number of Islamic scholars like Ali Abdul Raziq, Khalil Abdul Karim, Abdul Karim Soroush, Abdulahi Ahmed al-Naim and Farid Esack, Islamic revivalism represents transnational Islamic movement that proposes alternative to the existing democratic governmental framework of nation-state deemed to be non-Islamic. Democratic government is perceived as root cause of national and global poverty and social and

${ }^{3}$ Haedar Nashir, Gerakan Islam Syariah di Indonesia, Jakarta: PSAP, 2007. 
political injustice since this type of government is not under the guidance of God. In contrast, Islam-based government is conceived of just government since it is led by a khalifa under khilafa system as the most representative for Indonesian society. However, there has no convincing evidence about Islamic government which succeeds in bringing prosperity to Islamic societies, let alone its transparence. Historical record shows that governments in the tradition of political Islam have been marked with harsh bloody competition and lies. Several surveys suggest that a number of Islam-based states occupies the bottom list of states incapable of bringing welfare to the societies and political participation. There is strong reason to conclude that, as political ijtihad, Islam revivalists are undertaking their projects within circumstances prone to be misleading and negative. ${ }^{4}$

Many Muslim scholars have questioned the revivalist agenda. Including among them are An Naim, Ali Abdur Raziq, Azyumardi Azra, Syafii Maarif, Abdurrahman Wahid and Nurcholish Madjid. There are also another camp of scholars who support the idea of Islam as state foundation or conflation Islam and the state; among them are M. Natsir, Endang Syaifuddin Anshari, Anwar Harjono and Daud Rasyid. These two camps reveal how contentious the relation between Islam and Politics has been throughout Indonesian political history. The question is why not using democratic system in statecraftship and government, by making use democratic principles as something of political contract and consent in undertaking policies for the sake of general public of citizens. But this option is resisted by the revivalists who have been preoccupied with anti-democracy sentiments, while the efficacy of their own model (Islamic State) has no historical precedence.

\footnotetext{
${ }^{4}$ See Azyumardi Azra, Islam, Democracy and Indonesia, Jakarta: ICIP, 2007.
} 
Despite faced with recurrent failure, spirit of Pan-Islamism remains intact as the revivalists understand international order as disorder, unjust and in need of total transformation. Their resistance to democracy becomes more resilient in response to the global-international behaviors of Western power particularly USA in dealing with Muslim societies. While in fact, Pan-Islamism in Indonesia is the product of democratization that opens greater space of the revivalism like their counterparts in Middle East and Africa. Pan-Islamism in Indonesia has its own agenda, but the Indonesian government does not ban this movement.

However, it is almost impossible to imagine the emergence of PanIslamism within formal political articulation with the exception of HTI. The present condition of our political scene is laden with corruption and increasingly authoritarian. As we know, authoritarianism, monarchy and kekhalifaan share one fundamental characteristic, that is, they eliminate political competition. It serves completely to the interests of the ruling elite. This is another kind of state terrorism.

In Indonesia, Pan-Islamism is facing serious problems that stand in its way to the state arena. Political Islam in Indonesia reveals two faces that seem contradictory to each other. Islamic State and Islamic Society are two conflicting projects and the broader public takes side with the project of Islamic Society. Since the fall of Soeharto, particularly in 2001, echoes of the revivalism have occupied public mind and draw Islamic scholars and activists into long debate on that matters.

\section{Neo-traditionalist Islam}

Neo-traditionalist Islam represents progressive elements of Nadhlatul Ulama. It is a struggle for making Islam more indigenous. Though not very well crafted and less sounding, this movement must cope with the strong walls of Islam traditionalism in Indonesia. 
Abdurrahman Wahid is one among leading figure in this movement. His project of indigenization of Indonesian Islam elicits resistance from other religious leaders within NU. However, his attempts have resulted in ever increasing supports from young generations of NU whose agency is so important in reforming the movement. Johan Effendi (2009) argues that indigenization of Islam succeeds when PBNU was led by Abdurrahman Wahid. The success of this project is unquestionable since it does not create serious tension or fracture within the movement between the senior leaders and junior incumbents. Together with young NU activists, Abdurrahman Wahid cultivates renewed foundation for NU as the movement has to cope with the dynamics of Indonesian politics.

Under the Gus Dur leadership, NU has reached international community and gained international respect and sympathy. He introduced the movement into campuses, NGOs and civil society, more and more researchers from abroad come to study this movement and political Islam in general, some trends that have no historical precedence. In national level, NU becomes one of the major forces that help shape the post New Order politics, including its contribution for international peace and tolerance. The most affected segment is young generation within the movement. The following is the list of name that follows the Gus Dur's footsteps: Masdar Farid Masudi, MM Billah, Arief Mudasir, Abdul Munim, Imam Aziz, M. Fajrul Falaakh, Ahmad Suaedy, M. Jadul Maula with his well known LkiS, Ulil Abshar Abdlla with his Studi 68 in Jakarta, and Abd A'la in East Java. Of course, there are large number of young activists who has strong emotional and educational affiliation with Gus Dur, particularly as Gus Dur's students. During his leadership between 1989 and 2004, he has offered valuable contribution to the nation through reforming the movement to be capable of addressing 
the problems and challenge of this nation in post New Order politics and brought Indonesian Islam to the greater international public.

Those young activists mentioned above are offered broad space of engagement to articulate their Islamic spirits in the life of the nation. Though their efforts frequently resisted by older generation of NU leaders, they get 'protection' and 'defense' from Gus Dur. Legacy of Gus Dur's contribution to them can be easily seen in what have been done by the following organizations: P3M, LKiS, Lakpesdam NU, LKPSMNU, Rahima, Fahmina and many others. They are part of Gus Dur effort at building up intellectual tradition within NU. Once criticized as 'destructors of $\mathrm{NU}^{\prime}$, the organizations are now referred by international researchers and international NGOs. KH Abdul Qadir, KH Husein Muhammad, and $\mathrm{KH}$ Abdul Moqsith Ghazali are the successors of this progressive elements within NU.

There is also fundamental shift in the agenda of this neo-traditionalist Islam, from cultivation spirit of progress in civil society sectors to the cultivation of the spirit in pesantren (Islamic education). Young NU activists have brought ideas of progress and renewal into the Islamic schools. This project elicits resistance, but most of the Muslims accept the messages of the project. This success has much to do with the growing supports from senior leaders (Kiai) who share similar vision and appeal to reform the movement and Islam in general. This collaboration and support preclude the tension from within NU.

NU once labeled as traditionalist for being 'kampungan' (rural oriented) and 'lack' of attachment to modern technology and ways of life, and its theological understanding much more drawn from classical doctrines and teachings (Kitab Kuning). Now NU is considered more progressive compared to the older generation who in their time were perceived as reformers. Pros and cons are within the movement but 
more and more senior leaders support the reforming projects undertaken by the younger generations. This proves the efficacy of Gus Dur breakthrough when he introduced renewal in traditional pesantren with his idea of indigenization of Islam. ${ }^{5}$

Now the question is how the future of this project will take shape in coping with growing movements of purifying Islam? This question is important so as to ensure the position of neo-traditionalism amidst the trend. This question must be addressed by the post-Gus Dur generations who died in 2010, particularly under the leadership of KH Said Aqiel Siradj, whose leadership seems to go afar from what has been the golden legacy of Gus Dur period. This the challenge that KH Said Aqiel Siradj must deal with at present and in the next ten years. It is now that figure like Gus Dur is absent but efforts at reworking upon his legacy are urgent. His position is 'privileged' compared to other Kiai within NU, though their Islamic scholarship is at equal level with this great man.

KH Said Aqiel Siradj, KH Masdar Masudi, and KH Husen Muhammad within Tanfidhiyah field are figures whose Islamic scholarship is so great and enjoys great popularity, but their standing, so far, cannot be qualified at the level Gus Dur has achieved in relation to NU community in Indonesia. Other Islamic scholars and leaders like KH Ali Yafie, KH Sahal Mahfudz, and KH Faqih, known for their virtue and scholarship, also cannot be compared with Gus Dur achivement and charismatic leadership. Gus Dur has been placed among 'Kiai Langitan' (divine Kiai) together with his father KH Wahid Zaini and KH As'ad Syamsul Arifin.

Position and role of neo-traditionalist Islam in Indonesia have rapidly developed within the backdrop of emerging challenges brought about

${ }^{5}$ See Abdurrahman Wahid, Islamku, Islam Anda, Islam Kita, Jakarta: The Wahid Institute, 2008. 
by the bad performance of Islam politics including politicians of NU background. The case at hand is NU Muktamar (grand meeting) in Makassar in 2004. This meeting offers a picture of how the intrusion of political interests into this largest Islamic movement has been so deep and threatening its existence in the future. Money politics and political intrigues have characterized the meeting. If NU remains within this anti-democratic trend in matters of appointing its leaders, it will affect what has been achieved by neo-traditionalists and turn to be the threat to civil society for which both NU and Muhammadiyah have attempted to build up and defend in the last ten years. As we know, Indonesian politics in general has shown how money has driven political behaviors of the patron and clients. Within this condition, legacy of virtue and moral commitment, either at individual and organizational level, must continue for the best of the nation. To this challenge, NU can contribute the best of its performance and follow the footsteps its predecessors have left.

\section{Progressive Islam}

Progressive Islam or Muslim-progressive emerges from academic environment particularly campuses. Islamic student activists have built up and enlarged Islamic networks within campuses including developing cross-organizational alliances of NU and Muhammadiyah backgrounds. These progressive elements are now publicly known as Liberal Islam in Indonesia.

This term, liberal Islam, emerges for the first time when Omid Safi offered a preface to a book with the title 'Progressive Muslim' in 2004. Omid Safi argues that Islam in its development in Indonesia and other Muslim countries will be marked by a trend of engaging with issues of humanity and economic development such as human rights, poverty, 
social discrimination and violence. These are contemporary issues that relatively absent from debates among Muslims before twentieth century. But since the twentieth century these issues have become main concerns of the Muslim communities that crosscutting religious divide as perceived as human problems of this period. In national context, the issues hold together Muslims and non-Muslims within the boundaries of nation-state.

The presence of progressive Muslims brings promise of developing Islamic society and making the community more engaged with contemporary problems and challenges. It is obvious that today in dealing with human problems, forms of Islamic articulation or organizations no longer matter to the extent that substance is far greater important than appearance. In Indonesia, forms and format of articulation are the past legacy and contemporary Indonesia requires more genuine articulation toward better human life and democratic conditions. This era requires the active engagement of Islamic communities, and the latter cannot draw merely upon sharia formalization but substances of Islam can best offer to the society in Indonesia and in the world.

It is within this changing environment that new generation of Indonesian Muslims goes beyond organizations but without neglecting their respective traditions. While respecting their own traditions, either NU or Muhammadiyah, this new generation remains as collection of particularity but they seek to build up joint agenda. Being progressive Muslims do not distort their particularity as part of NU or Muhammadiyah. The progressive Muslims are those who always strike a balance between being part of the tradition and beyond as they become modern while at the same time good Muslims. This Islamic format and traits are required today for the future of the nation. We have explained this phenomenon of new generation of Muslims in Indonesian as we dis- 
cuss specifically liberal Islam in this country. ${ }^{6}$

In Indonesia, development of Progressive Islam in the future will be much determined by the persistence of spirits among its activists and jamaa (epistemic communities) whose task is to cultivate rational tradition of Islam, academic and independent in thinking rather than throwing themselves into intolerant self-standing and understanding. What the progressive Muslims must defend and spread is the urgency of going beyond simple minded ways of being Muslim that sometimes practice intolerance and underestimating other communities. In time when Indonesian society is in need of new direction of Indonesian Islam, progressive Muslims are called to undertake this project.

However, generation of progressive Muslims is not dominant though Indonesian Islam is characterized by its strong moderate culture as present within NU and Muhammadiyah movement. This might stem from the fact that many members of Muhammadiyah and NU still fear of renewal that perceived as controversial. For example, when issues like inter-faith dialog, gender equality and hermeneutics of al Quran are put into practice, support from members of Muhammadiyah are not so convincing and elicit resistance. It is also the case when NU brings forth the need to returning NU into pesantren and halts its orientation to political practices. Many Kiai resist this appeal as more and more of them get involved in politics.

\section{Neo-modernist Islam}

Neo-modernist Islam represents a model of Islam with strong inclusive-pluralist and more substantialist orientation rather than formalist

${ }^{6}$ Zuly Qodir, Islam Liberal, Yogyakarta: Pustaka Pelajar, 2004; Zuly Qodir, Islam Liberal, revised edition, Yogyakarta: Pustaka Pelajar, 2008. 
orientation. This is often in conflict with the formalization of Syariah in Indonesia such as model proposed by MMI, HTI, FPI and FUI.

Categorization of neo-modernist Islam has often been attached to Islamic scholars from Pakistan, Fazlur Rahman, while in Indonesia, it refers to Nurcholish Madjid and Ahmad Syafii Maarif, Rahman's student in Chicago University. Despite Nurcholish Madjid and Syafii Maarif, another Islamic scholars subject to this category are Abdurrahman Wahid and Djohan Effendi, including Ahmad Wahib. Greg Burton (1998), for instance, does not include Syafii Maarif into neo-modernist camp, while another M Syafii Anwar does include him into the category together with Jalaluddin Rakhmat, and even Taufik Abdullah. Azyumardi Azra and M. Amin Abdullah are also included as new generation of more substantialist ethics. ${ }^{7}$

By proposing the notion of Islam inclusiveness and substantialism, these neo-modernists clearly reject formalization of Islam into the form of state. Indonesian Islam is not formalist that enforces the state to be based upon Islam. Pancasila is perceived as proper and articulating Islamic values and pillar of political organizations. This is the reason for the proponents of this movement not to formalize Islam into the Indonesian state, let alone political project to establish Khiläfa Islämiya and khalifa as head of the state. The proponents engage more actively in bringing forth ethical principles of Islam and how such principles can contribute at best to the ways the state is managed in economic, social, political and legal terms. What matters for this movement is how to transform ethical idealism of Islam into practices of public life within the existing nation-state framework. It strongly envisions democratic and rational ways of undertaking the nation-state affairs in Indonesia.

7 Zuly Qodir, Pembaruan Pemikiran Islam, Yogyakarta: Pustaka Pelajar, 2006. 
For the proponents, Islamic idealism will be in conflict with existing reality of Indonesian society if such idealism is forcefully endorsed through formalization. They seek to adapt Islamic idealism into Indonesian circumstances. This requires very well crafted social engineering. The latter will be possible if Muslims are capable of placing Islamic norms into historical reality since if not properly placed there will emerge social clashes and cultural tensions. Concerning political Islam, Azyumardi Azra, for instance, prefers how ethics or substantial Islam can best influence political life and prosperity for Indonesians whose welfare remain below the tolerable level of poverty and underdevelopment. ${ }^{8}$

Amin Abdullah is another example of Islamic scholar who falls into substantialist category. In many of his writings, he introduces the need for properly employing Islamic ethics into public life. In matter of interreligious relationship, this scholar argues that social and religious relations must be separated as to what is confined to historical and normative realms. What is said to be absolute belongs to the normative realm while relative principles belong to historical realm. He locates Islam not in formalist terms but in position to reviewing the various interpretations that have been done by Islamic scholars and classical ulama in sixth and seventh Hijriya or thirteenth up to sixteenth century. Reinterpretation does not mean discrediting or underestimating their contributions but undertaken in ijtihad spirit and reconstructing new understanding based upon historical development of the societies. $^{9}$

Neo-modernist tradition in Islam has been the legacy of what Fazlur Rahman has instituted, an Islamic scholar whose contribution caused deep resistance in his own country, Pakistan, and removed into US

\footnotetext{
${ }^{8}$ Azyumardi Azra, Islam, Democracy and Indonesia, Jakarta: ICIP, 2007.

${ }^{9}$ M. Amin Abdullah, Dinamika Islam Indonesia Kontemporer, Bandung: Mizan, 2006.
} 
from where his ideas have spread through the Muslim world. His ideas have laid foundation for the rise of ulama and contemporary Muslim mujtahid. His writing on Ijtihad and Islam is an authentic articulation that empowers Muslims not to be misled by the contemporary debates, but this appeal is often misunderstood by Muslims themselves. Rahman has made an exodus to foreign country and spread his teachings. In Indonesia, neo-modernist Islam is obviously developed by Abdurrahman Wahid, Nurcholish madjid, Djohan Effendi, and recently, Amin Abdullah, Abdul Munir Mulkhan and Syafii Maarif.

\section{Sufism Islam}

Sufism Islam closely attached to what is called urban sufism. Urban sufism relates to the phenomenon of praying or dhikr akbar (grand dhikr), massive renewal and others by bringing into such activities dai or Ustadz of recent origin such as AA Gym, Arifin Ilham, Ustadz Haryono, ESQ Ari Gynanjar, dan many others.

Its development has been evident since 2000 in Indonesia. This Islamic tradition has been facilitated by the communication media particularly television. However, this also open greater space for the birth of 'dai selebriti' (media-popularized preacher) and also those who we might call 'dai karbitan' (new comer but actually incapable of being preacher). Their popularity has much to do with the logic of exploitation the media undertakes to gain profits. They do not have specific support bases or constituencies, not to mention of establishing or running pesantren, or having their own jamaa (community of prayers) in villages. Their jamaa are those who watch their preaching in television scene and their popularity depends on the media behavior and business interests. This is worrisome for the simple fact that the media is the master of their articulation and their presence is much more deter- 
mined by media framing and profit calculation. Once the media is disappointed with their performance, their virtual presence will end and their popularity declines.

Worth noticing is how the promotion of Sufism Islam in media exploits dramatic and melancholic ways of being Muslims as illustrated through collective praying in which the participants cry with tears falling down from their eyes under spotlighting. After the show, we have no idea of what activities the ustadz and his jamaa undertake in real life. It is interesting to argue that urban Sufism reflects the middle class trend of being Muslim with televised piety and virtue, and this also reveals 'class circle' quite distinct in Indonesian Islam today. Put in more direct way, this urban Sufism is a form of Islamic articulation that in fact give birth to 'lazy Islam', designed by media framing and outlook which celebrates glamour vision of religious life and crying for pity over one's unfortunate life. It looks at the poor in a distance that separates the viewer from the viewed. It negates the very fact of poverty into which majority of Muslims in real life is entrapped.

This format of Islam is not different from other fashions or events reproduced by the business media for profit accumulation. It celebrates the latest model of jilbab and baju koko (dress for male Muslims). This follows with what is called ritual of fashion show such as artist's wedding, mukena, al Quran and diamond). The presence of artists as dai like the late Gito Rolies, Hari Mukti, Neno Warisman, and Inneke Koes Herawati, Ratih Sanggarwati and Orbit-styled preaching with Din Syamsuddin, all these are part of popular Islam in Indonesia today. Even there has been trend in doing preaching through VCD, integral to media-framed preaching.

Since reform period of 1998 this popular Islam has developed relatively unimpeded. Since the 1999 general election, this urban Sufism 
has shifted their engagement from campuses and the world of artists into broader public of media targeting. All TV channels have dakwa programs. One ustadz and his/her jamaa join together in the form of tutorial model of preaching. It followed by collective praying and religious consultation with the help of a moderator, mostly artist. The phenomenon of urban Sufism has increasingly occupied the virtual public sphere compared to progressive Islam or neo-traditionalist Islam.

\section{Conclusion}

Multiple formats of Islam as we already expose suggest us to make sense of Indonesian Islam through its various articulations rather than only one variant. Drawn upon Habermasian point of view, ${ }^{10}$ these formats reflect the contention among Indonesian Muslims in their struggle for occupying and mastering the public sphere. All offer alternative to the sphere, by employing specific means and rational argumentation. Their language-game differs from each other and frequently modified so as to materialize their respective agenda and gain support and sympathy from broader Muslim public. It is true as Habermas argues that public sphere has been space of contention in which various interests including religious interests revolve together with political interests.

Political and religious interests go hand in hand since both are distinguishable but inseparable. Secularization has been the latest effort to differentiate religious matters from political affairs, and there also takes place a crosscutting between the two and not total separation. It is widely misunderstood that secularization means 'throwing the religion out of the state sphere'. What is actually taking place is that the values of religion contribute to the transformation and change in economic,

10 See Juergen Habermas, Structural Transformation of the Public Sphere, Great Britain: Polity Press, 1989; and Juergen Habermas, The Inclusion of Other, Cambridge: MIT Press, 1998. 
political and legal system that continuously reinvents political culture of the nation.

If one Islamic variant is forcefully introduced in Indonesia, it will surely result in social conflict and political violence. Religious interests, which is in the normative realm, should determine the course of political nature of the nation-state. Enforcement only produces discrimination and injustice within multicultural Indonesian society. Indonesia is a country of multiple cultures which have sociologically constituted what Indonesia is in the course of time. Indonesia is not a religious state but a religious society with hundreds years of experience of living together among various communities of different religious backgrounds. It was a time when this country called Nusantara, and then came Sukarno, Hatta, Syahrir and other enlightened youths who established Nusantara as modern Indonesia with clear cutting territorial and political frontiers.

It is within historical fact that today we are witnessing groups or movements that seek to articulate Islam while negate sociological reality of multicultural and religious Indonesian society. There have been two trends that is worth our attention, first, the persistence of the formalist or revivalist Islam that threats the very foundation of this state, and second, the popular or urban Sufism that denigrates the efficacy of Islam. Urban Sufism puts Islam at risk as this movement is subject to the interests of business media. The danger it poses is deep and real as it affects the ways Muslims (the audience) perceive what Islam is as spread by celebrity dai and ustadz. In contrast, progressive Islam, which is enlightening and emancipatory, has not been supported by the media. It is urban Sufism that takes the Muslims as its media's consumers, and loses its prophetic appeal and critical outlook at what the majority of Muslim, the mustad'afin, is now undergoing such poverty and social injustice in public sphere. 
To the question of which movement will be the winner of this contestation over Indonesian public sphere, the answer lies in how they seek broader support from Muslim communities such as pesantren, moderate Islamic organizations and also consistent support from media. However fragile the movement before the media, the movement must be able to strike the balance between autonomy and accommodation since the media has played major role in promoting Indonesian Islam at home and abroad. We will see the dynamics and development of Indonesian Islamic formats in future.

\section{Bibliography}

Abdullah, M. Amin. Dinamika Islam Indonesia Kontemporer. Bandung: Mizan, 2006.

Azra, Azyurmadi. Islam Substantif. Bandung: Mizan, 2004.

Azra, Azyumardi. Islam, Democracy and Indonesia. Jakarta: ICIP, 2007.

Effendi, Djohan. A Renewal Without Breaking Tradition. Yogyakarta: Interfidei, 2008.

Habermas, Juergen. Structural Transformation of the Public Sphere. Great Britain: Polity Press, 1989.

Habermas, Juergen. The Inclusion of Other. Cambridge: MIT Press, 1998.

Hardiman, F Budi. Ruang Publik. Yogyakarta: Kanisius, 2010.

Maarif, Ahmad Syafii. Islam dan Masalah Kenegaraan. Jakarta: LP3ES, 1987.

Maarif, Ahmad Syafii. Islam Keindonesiaan dan Kemanusiaan. Bandung: Mizan, 2009. 
Maliki, Zainuddin. Sosiologi Politik. Yogyakarta: Gajah Mada Press, 2010.

Nashir, Haedar. Gerakan Islam Syariah di Indonesia. Jakarta: PSAP, 2007.

Qodir, Zuly. Islam Liberal. Yogyakarta: Pustaka Pelajar, 2004.

Qodir, Zuly. Islam Liberal. revised edition, Yogyakarta: Pustaka Pelajar, 2008.

Qodir, Zuly. Pembaruan Pemikiran Islam. Yogyakarta: Pustaka Pelajar, 2006.

Wahid, Abdurrahman. Islamku, Islam Anda, Islam Kita. Jakarta: The Wahid Institute, 2008. 